\title{
Detection of Novel LAMC2 Mutations in Herlitz Junctional Epidermolysis Bullosa
}

\author{
Leena Pulkkinen, ${ }^{*}$ John McGrath, ${ }^{*}$ Tomi Airenne, ${ }^{\dagger}$ Heli Haakana, ${ }^{\dagger}$ \\ Karl Tryggvason," Sirpa Kivirikko,* Guerrino Meneguzzi, ${ }^{*}$ \\ Jean-Paul Ortonne, ${ }^{\neq}$Angela M. Christiano,* and Jouni Uitto* \\ *Departments of Dermatology and Cutaneous Biology, and \\ Biochemistry and Molecular Pharmacology, Jefferson Medical College, \\ and Section of Molecular Dermatology, Jefferson Institute of \\ Molecular Medicine, Thomas Jefferson University, Philadelphia, \\ Pennsylvania, U.S.A. ${ }^{\dagger}$ Biocenter Oulu and Department of \\ Biochemistry, University of Oulu, Oulu, Finland "Department of \\ Medical Biochemistry and Biophysics, Karolinska Institute, Stockholm, \\ Sweden ${ }^{\ddagger}$ University of Nice, INSERM U385, Nice, France
}

\begin{abstract}
Background: Laminin 5, an anchoring filament attachment protein within the lamina lucida of the basement membrane zone involved in the pathogenesis of junctional epidermolysis bullosa (JEB), consists of three polypeptide subunits, the $\alpha 3, \beta 3$, and $\gamma 2$ chains, which are encoded by the $L A M A 3, L A M B 3$, and $L A M C 2$ genes, respectively. To facilitate identification of pathogenetic mutations in $L A M C 2$, a strategy based on direct amplification of genomic DNA by PCR or mRNA by RT-PCR, followed by heteroduplex analysis of the PCR products, was developed.

Materials and Methods: Primer pairs for amplification of the complete cDNA as well as the 23 individual exons in the genomic DNA, which encode the entire $\gamma 2$ chain of laminin 5, were established. The primers for amplification of exons from genomic DNA were positioned at least 24 bp away from the intron-exon borders in the flanking intronic sequences. For amplification of cDNA
\end{abstract}

generated by RT-PCR, eight primer pairs covering overlapping segments of the entire coding sequence of $L A M C 2$ mRNA were used. The amplified sequences were scanned for pathogenetic mutations and sequence variations in JEB patients and unrelated control individuals by heteroduplex analysis by means of conformation sensitive gel electrophoresis (CSGE).

Results: Utilizing the strategy developed in this study, we identified pathogenetic mutations in three patients with the Herlitz (lethal) variant of JEB, and eight intragenic normal polymorphisms, which are useful for linkage analysis, in the $L A M C 2$ gene.

Conclusions: The methodology described in this study is capable of detecting single-base substitutions or small insertions and deletions in the $L A M C 2$ gene. Demonstration of mutations in this gene in JEB patients further emphasizes the role of laminin 5 in providing integrity to the cutaneous basement membrane zone.

\section{INTRODUCTION}

Laminins comprise a family of heterotrimeric extracellular matrix proteins associated with basement membranes in a diverse tissue distribution

Address correspondence and reprint requests to: Jouni Uitto, Department of Dermatology and Cutaneous Biology, Jefferson Medical College, 233 South 10th Street, Suite 450, Bluemle Life Sciences Building, Philadelphia, PA 19107, U.S.A.

Leena Pulkkinen's permanent address is Department of Obstetrics and Gynecology, Division of Medical Genetics, Kuopio University Hospital, Kuopio, Finland.
$(1,2)$. Each of the laminins is composed of three polypeptide chains, $\alpha, \beta$, and $\gamma$, which form a cross-shaped trimeric structure, assembled through association of the carboxy-terminal segments of the polypeptides. The amino-terminal short arms remain as individual domains containing globular and cysteine-rich segments.

Laminin 5, a member of the laminin family of proteins, consists of three subunit polypeptides, the $\alpha 3, \beta 3$, and $\gamma 2$ chains (1). It is primarily expressed in the basement membranes of strati- 
fying squamous epithelia, as exemplified by the cutaneous dermal-epidermal basement membrane zone (BMZ). Recently, the primary structures of the three polypeptide chains of laminin 5 have been characterized through molecular cloning of the corresponding cDNAs (3-7). The laminin 5 polypeptides were predicted to be truncated when compared with the corresponding chains, $\alpha 1, \beta 1$, and $\gamma 1$, of classical laminin 1 . Specifically, the globular domain IV in the short arm of the $\beta 3$ chain was absent, and the globular domain VI and part of the cysteine-rich repeat III were missing in the $\gamma 2$ chain when these sequences were compared with the corresponding sequences in laminin $1(3,4)$. Furthermore, characterization of the $\alpha 3$ chain demonstrated polypeptide chains with two truncated aminoterminal short arms that are different from those of the $\alpha$ l chain $(5,7)$. These structural differences suggest that laminin 5 must be functionally different from laminin 1 as well as from other known laminins, implicating a tissue-specific role for laminin 5 within the cutaneous BMZ. The genomic structures of the $\beta 3$ and $\gamma 2$ chain genes, $L A M B 3$ and $L A M C 2$, have also been characterized $(8,9)$. Both of them contain 23 exons spanning approximately 28 and $55 \mathrm{~kb}$ of genomic DNA at the chromosomal loci 1q32 and lq25-31, respectively $(3,4,10)$. Characterization of the $\alpha 3$ chain gene, LAMA3, is still incomplete, but the gene has been mapped to the long arm of human chromosome 18 (5).

The interest in laminin 5 derives in part from the fact that the corresponding genes, LAMA3, $L A M B 3$, and $L A M C 2$, are involved in the pathogenesis of a heritable blistering skin disease, junctional epidermolysis bullosa (JEB). In fact, recent cloning of human cDNA and genomic sequences for these genes has allowed elucidation of specific mutations in different forms of JEB (11-15).

To facilitate the detection of sequence variants in the $L A M C 2$ gene, we have developed a mutation detection strategy based on PCR amplification of all 23 exons of this gene (9), followed by heteroduplex analysis with conformation sensitive gel electrophoresis (CSGE) (16), and direct nucleotide sequencing of the PCR products. We also report optimized conditions for amplification of genomic DNA by PCR and mRNA sequences by RT-PCR. Through these strategies, the presence of novel pathogenetic mutations in families with the lethal, Herlitz type of JEB $(\mathrm{H}-$ JEB) as well as several polymorphic variants in the $L A M C 2$ gene were revealed.

\section{MATERIALS AND METHODS}

\section{PCR Amplification and Mutation Detection}

To amplify each of the 23 exons of the LAMC2 gene directly from genomic DNA, primer pairs were positioned within the introns flanking each exon (Table 1). The primer pairs were designed by Primer Designer, Educational Software, Version 3.0. For PCR, $200 \mathrm{ng}$ of genomic DNA was used as a template under standard conditions, including $10 \times$ PCR buffer (Perkin-Elmer Cetus), 4\% DMSO, and $1.25 \mathrm{U}$ AmpliTaq (Perkin-Elmer Cetus) in a total volume of $50 \mu \mathrm{l}$. RNA isolated from fibroblast or keratinocyte cultures derived from JEB patients' skin was used as a template for RT-PCR of the $L A M C 2$ gene sequences. Firststrand cDNA was prepared from $50 \mu \mathrm{g}$ of total RNA in a reaction containing $25 \mathrm{ng} / \mu \mathrm{l}$ of oligo(dT), $0.5 \mathrm{mM}$ dNTP, and $2.5 \mathrm{U} / \mu \mathrm{l}$ of $\mathrm{M}-\mathrm{MLV}$ reverse transcriptase (BRL) in a total volume of $100 \mu \mathrm{l}$. One microliter of the reaction containing CDNA was used as a template for PCR reactions with eight separate primer pairs, resulting in synthesis of overlapping PCR products that span the entire coding sequence of the $L A M C 2$ mRNA. The primers used for amplification of mRNA segments are listed in Table 2. The conditions for PCR amplification were $94^{\circ} \mathrm{C}$ for $5 \mathrm{~min}$, followed by $45 \mathrm{sec}$ at $95^{\circ} \mathrm{C}, 45 \mathrm{sec}$ at annealing temperature of the primers (see Tables 1 and 2), and 45 sec at $72^{\circ} \mathrm{C}$, for 35 cycles. All PCR-reactions were optimized using an Omnigene thermocycler $(\mathrm{Hy}$ baid). The PCR products were examined by electrophoresis on $2-3 \%$ agarose gels, followed by heteroduplex analysis using conformation sensitive gel electrophoresis (CSGE) as described by Ganguly et al. (16). Briefly, PCR products were analyzed on CSGE gel that contained $40 \%$ of 99:1 acrylamide:BAP [1.4 bis(acryoyl) piperazine], $0.5 \times$ GT buffer (USB), $15 \%$ formamide, $10 \%$ ethylene glycol, $0.1 \%$ ammonium persulfate, and $0.07 \%$ TEMED (16). The PCR products (100-300 ng) were denatured at $95^{\circ} \mathrm{C}$ for $5 \mathrm{~min}$ followed by incubation at $68^{\circ} \mathrm{C}$ for $30-60 \mathrm{~min}$. Samples were run on CSGE gel overnight with $350 \mathrm{~V}$, followed by staining with ethidium bromide and visualization under UV light. To detect homozygous mutations, control DNA from the PCR reaction was mixed with amplified patient DNA. PCR products displaying heteroduplexes were sequenced by direct automated sequencing (Applied Biosystems). 
TABLE 1. Primers for PCR amplification of the LAMC2 exon sequences from genomic DNA

\begin{tabular}{|c|c|c|c|c|}
\hline Exon No. & $5^{\prime}$-primer $(\mathbf{L})^{a}$ & $3^{\prime}$-primer $(\mathbf{R})^{a}$ & $\begin{array}{l}\text { Annealing Temp. } \\
\left({ }^{\circ} \mathrm{C}\right)\end{array}$ & $\begin{array}{l}\text { Product Size } \\
\text { (bp) }\end{array}$ \\
\hline 1 & $\begin{array}{l}\text { ggctctcttcctgtcaggac } \\
-70\end{array}$ & $\begin{array}{l}\text { gaggtacgttcagccatcac } \\
+85\end{array}$ & 60 & 324 \\
\hline 2 & $\begin{array}{l}\text { gacgatctcttttgtatgct } \\
-30\end{array}$ & $\begin{array}{l}\text { gttgttccettccttcttct } \\
+96\end{array}$ & 55 & 315 \\
\hline 3 & $\begin{array}{l}\text { gcttctaatgccgcatacat } \\
-69\end{array}$ & $\begin{array}{l}\text { ctcaaagcagtgtttggcac } \\
+114\end{array}$ & 60 & 319 \\
\hline 4 & $\begin{array}{l}\text { gttgtgaagcatttggaagc } \\
-52\end{array}$ & $\begin{array}{l}\text { ctagttgggcaagggactct } \\
+54\end{array}$ & 55 & 205 \\
\hline 5 & $\begin{array}{l}\text { cctgatttctacaatgccac } \\
-25\end{array}$ & $\begin{array}{l}\text { caaagcctgtacaacatta } \\
+53\end{array}$ & 55 & 215 \\
\hline 6 & $\begin{array}{l}\text { atagatgatgagggcttgtc } \\
-50\end{array}$ & $\begin{array}{l}\text { tcctagtcctataagctggc } \\
+49\end{array}$ & 55 & 222 \\
\hline 7 & $\begin{array}{l}\text { tcatagcccaaagtgtcata } \\
-177\end{array}$ & $\begin{array}{l}\text { aggcttgttgaacaaatgaa } \\
+102\end{array}$ & 60 & 469 \\
\hline 8 & $\begin{array}{l}\text { ggtatgtggtaagaatcgga } \\
-51\end{array}$ & $\begin{array}{l}\text { ctacttgtttggagactgcc } \\
+93\end{array}$ & 55 & 255 \\
\hline 9 & $\begin{array}{l}\text { ctttagactgtaccacttgc } \\
-48\end{array}$ & $\begin{array}{l}\text { gtctttcttacacagctctc } \\
+71\end{array}$ & 60 & 338 \\
\hline 10 & $\begin{array}{l}\text { attgtctgaccetgctcact } \\
-52\end{array}$ & $\begin{array}{l}\text { cagagcagacccatggcctt } \\
+22\end{array}$ & 60 & 257 \\
\hline 11 & $\begin{array}{l}\text { cctaggcttggtcatttgtt } \\
-30\end{array}$ & $\begin{array}{l}\text { aagtgcatacgtacacaggc } \\
+56\end{array}$ & 60 & 332 \\
\hline 12 & $\begin{array}{l}\text { aaggattctctgctgttgga } \\
-106\end{array}$ & $\begin{array}{l}\text { acagaacacccagtggacac } \\
+72\end{array}$ & 60 & 321 \\
\hline 13 & $\begin{array}{l}\text { gtattggatgatcccttggg } \\
-65\end{array}$ & $\begin{array}{l}\text { cctaacgtagccattccttc } \\
+68\end{array}$ & 55 & 290 \\
\hline 14 & $\begin{array}{l}\text { ttgctaactctatgctgacc } \\
-60\end{array}$ & $\begin{array}{l}\text { tctacaagtaggtctcccaa } \\
+61\end{array}$ & 55 & 326 \\
\hline 15 & $\begin{array}{l}\text { aatggtgaatagaggcatgg } \\
-134\end{array}$ & $\begin{array}{l}\text { aaactggtttcaaggtaggg } \\
+148\end{array}$ & 60 & 362 \\
\hline 16 & $\begin{array}{l}\text { ctaaatcagaccagctcccg } \\
-104\end{array}$ & $\begin{array}{l}\text { ttacaactagcatggtgccc } \\
+95\end{array}$ & 60 & 357 \\
\hline 17 & $\begin{array}{l}\text { agtcctctttttattaccgc } \\
-43\end{array}$ & $\begin{array}{l}\text { agaaagtatttatggccctc } \\
+54\end{array}$ & 55 & 242 \\
\hline 18 & $\begin{array}{l}\text { ggtgtggtaactggtaagca } \\
-54\end{array}$ & $\begin{array}{l}\text { tattcatatggtgggcattc } \\
+60\end{array}$ & 55 & 267 \\
\hline 19 & $\begin{array}{l}\text { gtcagagtgattttgccagc } \\
-64\end{array}$ & $\begin{array}{l}\text { caaaggaaattggtcatgac } \\
+66\end{array}$ & 55 & 245 \\
\hline 20 & $\begin{array}{l}\text { tttgctttcatcttcacggc } \\
-44\end{array}$ & $\begin{array}{l}\text { tttccctccacaccaccctt } \\
+65\end{array}$ & 55 & 299 \\
\hline 21 & $\begin{array}{l}\text { ctatggttgtctttgggatg } \\
-76\end{array}$ & $\begin{array}{l}\text { ataagcacaaaccagccttg } \\
+83\end{array}$ & 55 & 318 \\
\hline 22 & $\begin{array}{l}\text { gggagatccctttcaacttg } \\
-71\end{array}$ & $\begin{array}{l}\text { tgagtgttctggagcaaagc } \\
+65\end{array}$ & 55 & 236 \\
\hline 23 & $\begin{array}{l}\text { agttatgggtatagaagggc } \\
-86\end{array}$ & $\begin{array}{l}\text { tgacctgagcatacccatta } \\
3821 \text { in cDNA }\end{array}$ & 55 & 462 \\
\hline
\end{tabular}

${ }^{a}$ The numbers under each primer refer to the position of their $5^{\prime}$ end within the introns in relation to the intron-exon border (upstream in the case of $5^{\prime}$-primers and downstream in the case of $3^{\prime}$-primers; the numbers are according to Airenne et al., 1996 [9]; GenBank accession nos. U31178-U31201). 
TABLE 2. Primer pairs for amplification of LAMC2 CDNA sequences by RT-PCR

\begin{tabular}{|c|c|c|c|c|}
\hline Primer & Position $^{a}$ & Sequence & $\begin{array}{c}\text { Annealing } \\
\text { Temperature } \\
\left({ }^{\circ} \mathrm{C}\right)\end{array}$ & $\begin{array}{l}\text { Product } \\
\text { Size } \\
\text { (bp) }\end{array}$ \\
\hline $1 \mathrm{~L}$ & 35 & 5'-GAGCGCAGAGTGAGAACCAC-3' & 60 & 691 \\
\hline $1 \mathrm{R}$ & 726 & 5'-ACTGTATTCTGCAGAGCTGC-3' & & \\
\hline $2 \mathrm{~L}$ & 706 & 5'-CGCAGCTCTGCAGAATACAG-3' & 60 & 439 \\
\hline $2 \mathrm{R}$ & 1145 & 5'-AGATTCCGCAGTAACCTTCG-3' & & \\
\hline $3 \mathrm{~L}$ & 1046 & 5'-GGCTCACCAAGACTTACACA-3' & 60 & 491 \\
\hline $3 R$ & 1537 & 5'-GAATCACTGAGCAGCTGAAC-3' & & \\
\hline $4 \mathrm{~L}$ & 1430 & 5'-CTGACATTGAGTGTGCTGAC-3' & 60 & 453 \\
\hline $4 \mathrm{R}$ & 1883 & 5'-CCATCACTTCGACATCCTAC-3' & & \\
\hline $5 \mathrm{~L}$ & 1854 & 5'-CTCAGAGCCTGTAGGATGTC-3' & 60 & 501 \\
\hline $5 \mathrm{R}$ & 2355 & 5'-GTCTGAGGCAGGAATGTTAG-3' & & \\
\hline $6 \mathrm{~L}$ & 2248 & 5'-CAGTACCAGAACCGAGTTCG-3' & 60 & 529 \\
\hline $6 \mathrm{R}$ & 2777 & 5'-CTGGTTACCAGGCTTGAGAG-3' & & \\
\hline $7 \mathrm{~L}$ & 2674 & 5'-GATTCAGTGTCTCCGCTTCA-3' & 56 & 539 \\
\hline $7 \mathrm{R}$ & 3213 & 5'-GGCTTCCAAGTTCAGACTCC-3' & & \\
\hline $8 \mathrm{~L}$ & 3168 & 5'-CTCCAGTGAGATTGAACAGG-3' & 62 & 534 \\
\hline $8 \mathrm{R}$ & 3702 & 5'-GCTTCACTGTTGCTCAAGAG-3' & & \\
\hline
\end{tabular}

${ }^{a}$ The numbers indicate the nucleotide position in the published cDNA sequence (Kallunki et al., 1992 [3]; GenBank accession nos Z15008 and Z15009).

\section{Verification of Pathogenetic Mutations and Sequence Variants}

Sequence variants were verified from amplified genomic DNA in the region of the nucleotide change. Whenever possible, the PCR products were analyzed using restriction enzyme digestions, followed by analysis of the products on agarose gels. If the genetic variation did not change a restriction enzyme site, the PCR products containing the sequence variant were analyzed by allele-specific oligonucleotide hybridization (ASO) (17). The oligomers were $5^{\prime}$ end labeled with $\gamma-\left[{ }^{32} \mathrm{P}\right] \mathrm{dATP}$, hybridizations were performed at $37^{\circ} \mathrm{C}$ for $1 \mathrm{hr}$, and the filters were washed with $2 \times \mathrm{SSPE} / 0.1 \%$ SDS at the $\mathrm{T}_{\mathrm{m}}$ of the oligomers.

\section{RESULTS \\ Strategies for Amplification of $L A M C 2$ Sequences}

The design of primer pairs for amplification of genomic DNA sequences was based on delineation of the exon-intron organization of the entire $L A M C 2$ gene which consists of 23 exons spanning $\sim 55 \mathrm{~kb}$ of genomic DNA on the long arm of human chromosome $1(3,9,10)$. For amplification of individual exons using genomic DNA as template, the primers were positioned within the intronic sequences adjacent to the exon-intron borders. The primer sequences, the corresponding annealing temperatures, and the expected sizes of the PCR products are indicated in Table 1. The primers were tested using DNA 

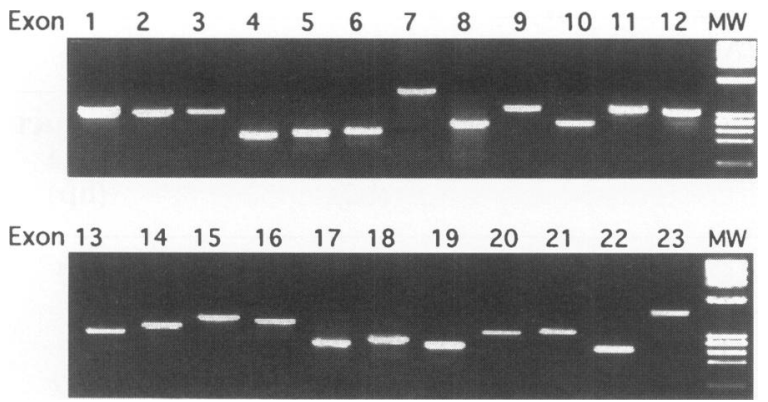

FIG. 1. PCR amplification of exons 1-23 of the LAMC2 gene using genomic DNA as template with the primer pairs shown in Table 1

The PCR products were examined by $3 \%$ agarose gel electrophoresis. The lanes marked MW contain HaeIII digested $\phi$ X174 molecular weight markers.

isolated from peripheral blood of control individuals as template, and the PCR products were examined on $3 \%$ agarose gels. Distinct PCR products of the expected molecular sizes were obtained under the optimized conditions for each primer pair (Fig. 1). For amplification of cDNA sequences generated by RT-PCR amplifi- cation of mRNA as template (see Materials and Methods), eight primer pairs amplifying overlapping mRNA sequences were also designed (Table 2). PCR products of the expected sizes were obtained with each primer pair (results not shown). The use of these primers for amplification of mRNA sequences by RT-PCR has been demonstrated previously (18-21).

The PCR amplification products were scanned by CSGE analysis to screen for sequence variants both in normal control individuals and in patients with JEB. In the presence of a band with altered electrophoretic mobility on the CSGE gel, the corresponding PCR product was subjected to direct nucleotide sequencing. Using this approach, we have identified eight allelic polymorphisms present in the population at large, as indicated in Table 3.

\section{Demonstration of Novel Mutations in Patients with H-JEB}

The strategy described above for the detection of sequence variants has disclosed putative pathogenetic mutations in patients with JEB.

TABLE 3. Polymorphisms in the LAMC2 gene

\begin{tabular}{|c|c|c|c|c|c|c|}
\hline \multirow[b]{2}{*}{ Location } & \multirow{2}{*}{$\begin{array}{l}\text { Nucleotide } \\
\text { Position }^{a}\end{array}$} & \multicolumn{2}{|c|}{ Allellic polymorphisms } & \multirow{2}{*}{$\begin{array}{l}\text { Detection } \\
\text { Method }^{b}\end{array}$} & \multirow[b]{2}{*}{ Allelic Frequency ${ }^{c}$} & \multirow{2}{*}{$\begin{array}{c}\text { PIC } \\
\text { Value }\end{array}$} \\
\hline & & Major & Minor & & & \\
\hline Exon 1 & 80 & $\mathrm{C}$ & G & PstI & $\begin{array}{l}0.92 / 0.08 \\
\quad(100 \text { chromosomes })\end{array}$ & 0.138 \\
\hline Exon 1 & 112 & $\mathrm{~A}$ & $\mathrm{C}$ & Ms II & $\begin{array}{l}0.75 / 0.25 \\
\quad(32 \text { chromosomes })\end{array}$ & 0.305 \\
\hline Exon 3 & 414 & TCE $($ Ser) & TCT (Ser) & $B s p \mathrm{EI}$ & $\begin{array}{l}0.76 / 0.24 \\
\quad(100 \text { chromosomes })\end{array}$ & 0.300 \\
\hline Exon 4 & 601 & GTC $(\mathrm{Val})$ & GTT (Val) & $T s p \mathrm{RI}$ & $\begin{array}{l}0.63 / 0.37 \\
\quad(36 \text { chromosomes })\end{array}$ & 0.358 \\
\hline Exon 7 & 915 & GGG (Gly) & GGT (Gly) & Seq & $\mathrm{n} / \mathrm{d}$ & - \\
\hline Intron 7 & $1070+37$ & A & G & Seq & $\mathrm{n} / \mathrm{d}$ & - \\
\hline Exon 14 & 2315 & AG $\underline{T}$ (Ser) & ACT (Thr) & $A l w \mathrm{NI}$ & $\begin{array}{l}0.66 / 0.34 \\
\quad(68 \text { chromosomes })\end{array}$ & 0.3481 \\
\hline Exon 18 & 2805 & CAA (Gln) & CAG (Gln) & Seq & $\mathrm{n} / \mathrm{d}$ & - \\
\hline
\end{tabular}

${ }^{a}$ Numbers refer to the published cDNA sequence (3).

${ }^{b}$ The polymorphisms change the restriction sites for the endonucleases listed; in cases in which no change in a restriction enzyme site is observed, the polymorphism was detected by direct sequencing (Seq).

$c^{n} / \mathrm{d}$, not determined. 

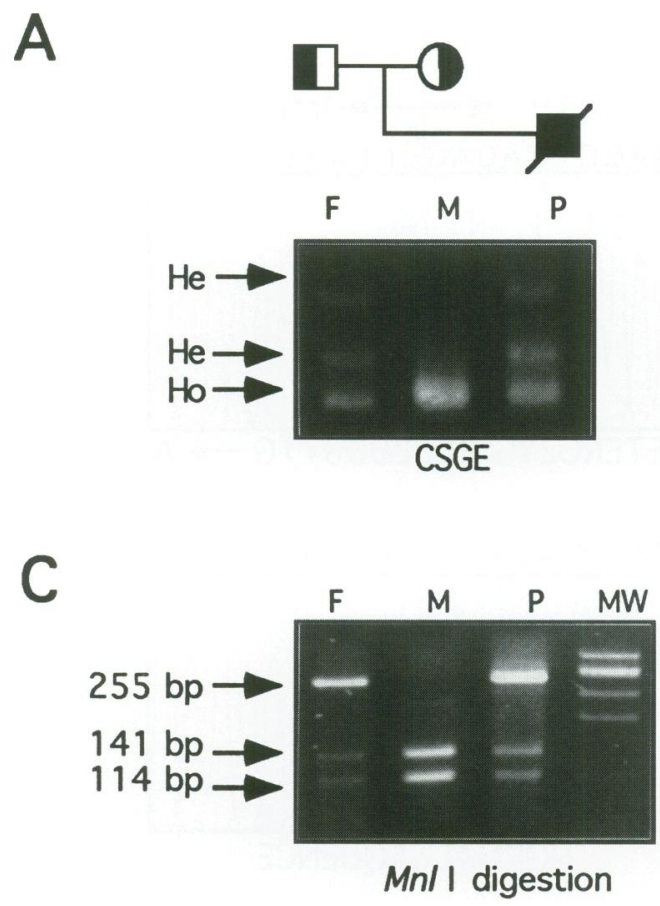

B

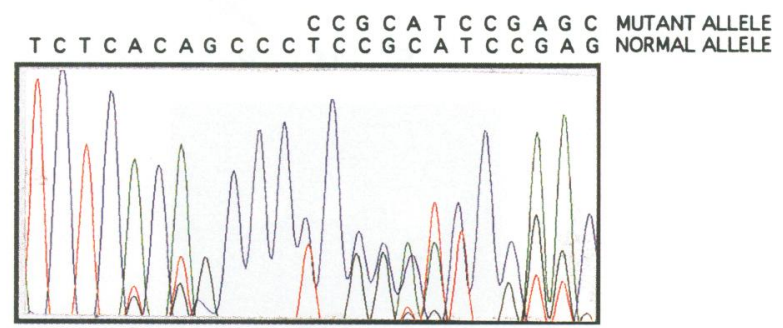

HETEROZYGOUS 1154 delT

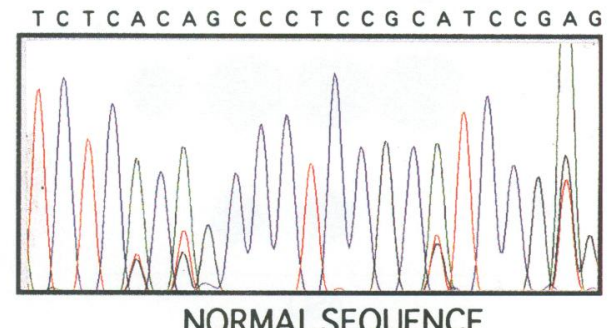

NORMALSEQUENCE

FIG. 2. Demonstration of the paternal mutation in LAMC2 in the proband with H-JEB in Family 1

(A) Conformation sensitive gel electrophoresis (CSGE) of DNA spanning exon 8 and flanking intronic sequences demonstrates heteroduplex bands (He) with the father's (F) and the proband's (P) DNA, while the mother (M) shows a homoduplex band (Ho) only. (B) Direct automated sequencing of the proband's PCR product reveals a heterozygous deletion of $\mathrm{T}$ at nucleotide position 1154 (upper panel) when compared with the normal sequence (lower panel). (C) The mutation results in the loss of a restriction enzyme site for $M n l$, which cuts the normal allele to 141 and $114 \mathrm{bp}$ bands, whereas the mutant allele remains $255 \mathrm{bp}$ in size (MW, molecular weight marker $\phi \mathrm{X} 174$ digested with HaeIII).

FAMILY 1. One of the patients, previously undescribed, was a newborn male with classical $\mathrm{H}$ JEB, who died from complications of this disease at the age of 2 months. Electron microscopy demonstrated the cleavage plane at the level of the lamina lucida, and immunofluorescence was negative with the anti-laminin 5 antibody, GB3 (22). Examination of PCR products spanning exon 8 of $L A M C 2$ revealed two heteroduplex bands with the proband's and his father's amplified DNA (Fig. 2A). The mother's DNA showed a homoduplex band only (Fig. 2A), similar to those seen in unrelated healthy controls (not shown). Direct sequencing of the PCR products depicting the heteroduplexes indicated a $1 \mathrm{bp}$ deletion, $\mathrm{T}$ in position 1154 (GenBank accession nos. Z15008 and Z15009) (3) (Fig. 2B). This mutation, 1154delT, results in a frameshift and a premature termination codon 51 bp downstream from the nucleotide deletion. This mutation resulted in the loss of a restriction enzyme site for $M n l$. In the case of controls and the proband's mother, the $255 \mathrm{bp}$ PCR product containing exon
8 and flanking intronic sequences was completely digested to 141 and $114 \mathrm{bp}$ fragments (Fig. 2C). In the proband's and the father's DNA, one of the alleles was not digested by MnII, indicating that they were both heterozygous for this mutation (Fig. 2C).

In search of the mutation in the maternal $L A M C 2$ allele, broadening of the PCR product spanning exon 19 on the heteroduplex gel was observed in the proband's and the mother's DNA, in contrast to the father's DNA (Fig. 3A). Sequencing of this PCR product demonstrated a G-to-A transition in the first nucleotide of intron 19 (GenBank accession nos. U31178-U31201) (9) (Fig. 3B). This mutation, 2986+l G $\rightarrow$ A, abolished the canonical 5 '-donor splice site consensus sequence, exon-gt. Thus, this mutation predicts out-of-frame skipping of exon 19, which consists of $115 \mathrm{bp}$, potentially resulting in a premature termination codon within exon 20 . However, cells were not available to test this hypothesis at the mRNA level. This G-to-A substitution did not alter any restriction enzyme site. Thus, 
A
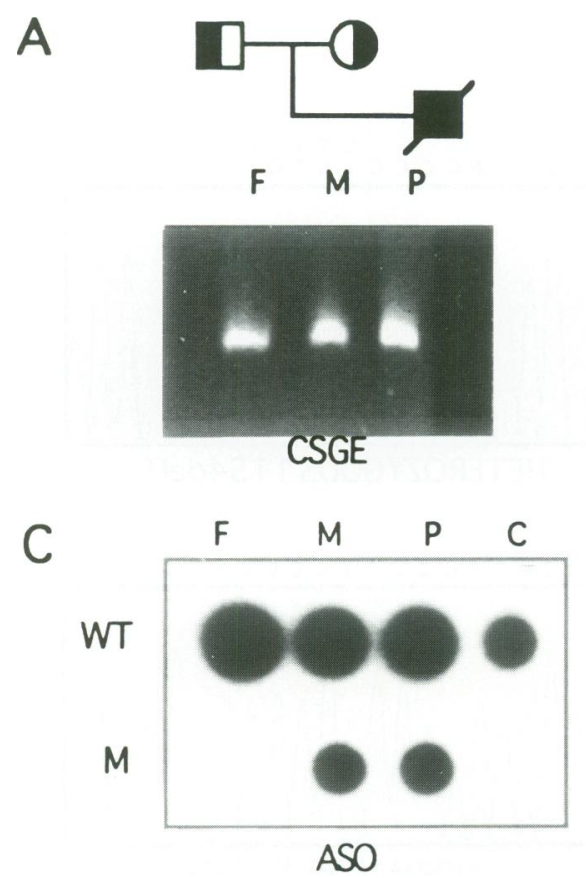

B
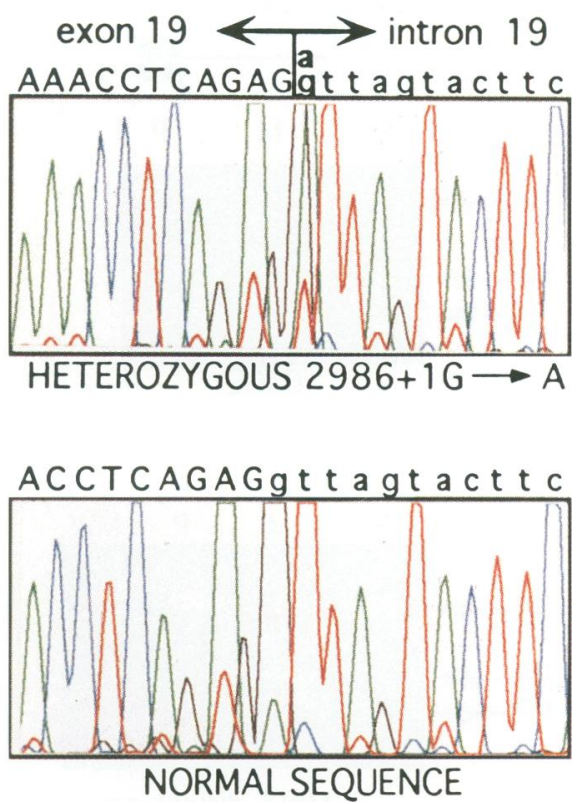

FIG. 3. Demonstration of the maternal $L A M C 2$ mutation in Family 1

(A) Conformation sensitive gel electrophoresis (CSGE) of exon 19 and flanking intronic sequences reveals broadened bands with the mother's (M) and the proband's (P) DNA, when compared with DNA from the father (F) and normal controls (not shown). (B) Direct nucleotide sequencing of the proband's PCR product reveals a heterozygous G-to-A transition at the 5' donor splice site of intron 19 (upper panel) when compared with the normal sequence (lower panel). Upper case represents the coding sequence; lower case represents the intronic sequences. (C) The mutation was verified by allele-specific oligonucleotide hybridization (ASO) with oligomers corresponding to the wild-type (WT) and mutant (M) alleles and using PCR products of the father's (F), mother's (M), proband's (P), and normal control (C) DNA. The sequences for oligomers used for hybridization were: WT, 5'-ACCTCAGAGGTTAGTACTTC-3'; M, 5'-ACCTCAGAGATTAGTACTTC- $3^{\prime}$. The $\mathrm{T}_{\mathrm{m}}$ values of these oligomers were $58^{\circ} \mathrm{C}$ and $56^{\circ} \mathrm{C}$, respectively.

the presence or absence of this mutation in the parents' and the patient's DNA was tested by ASO. The results indicated that the patient's as well as the mother's DNA hybridized with oligomers containing both the wild-type and the mutated sequence (Fig. 3C). In contrast, the father's DNA was homozygous for the wild-type sequence, which is identical to an unrelated healthy control (Fig. 3C). Thus, the patient was a compound heterozygote, 1154delT/2986+1G $\rightarrow$ A, potentially resulting in premature termination codons in both $L A M C 2$ alleles.

FAMILY 2. The proband in the second family was a newborn female who died from complications of H-JEB. The diagnosis was based on clinical observations and negative immunofluorescence staining for laminin 5. Mutation detection analysis revealed a heteroduplex band when the proband's and her father's PCR product spanning exon 18 was examined by CSGE. Direct sequencing revealed a $\mathrm{C}$-to- $\mathrm{T}$ transition at nucleotide position 2740 (GenBank accession nos. Z15008 and Z15009) (3). This nucleotide change resulted in substitution of a codon for Gln (CAA) by a termination codon (TAA), and the mutation was designated as Q895X (results not shown). We were unable to disclose the maternal mutation in the proband either by heteroduplex scanning or direct sequencing of the entire coding region and flanking intronic sequences.

FAMILY 3. The proband in the third family was a newborn male with clinical features of H-JEB. Immunofluorescence was negative for the laminin $5 \gamma 2$ polypeptide using a chain-specific antibody. Through the mutation detection strategy, a homozygous mutation R95X was found in the proband, and the parents were heterozygous carriers of this mutation, which is similar to what 
has been previously described in an another family (18). It is of interest that both of the probands homozygous for the $\mathrm{R} 95 \mathrm{X}$ mutation reside in the southern part of Italy.

\section{DISCUSSION}

The heritable forms of epidermolysis bullosa (EB) are characterized by fragility of the skin as well as other epithelial surfaces, including the mucous membranes of the gastrointestinal, respiratory, and urinary tracts $(11,13,23)$. The affected area of skin forms blisters and becomes denuded after minor physical trauma. EB can be divided into three major categories on the basis of the level of tissue separation within the dermal-epidermal junction: ( 1 ) in the simplex forms of EB, tissue separation occurs within basal keratinocytes of the epidermis; (2) in the junctional forms of EB, blister formation takes place within the dermal-epidermal basement membrane at the level of the lamina lucida; and (3) in the dystrophic forms of EB, the tissue separation occurs within the upper papillary dermis at the level of the anchoring fibrils. Through correlative electron microscopy, recent elucidation of the structural components of the cutaneous basement membrane zone at the molecular level has allowed identification of candidate genes for different forms of EB, and a number of specific mutations have been demonstrated in such genes (13-15). In the classic, dominantly inherited simplex forms of EB, the mutations reside in the keratin genes, KRT5 and KRT14, resulting in fragility of the basal cells (24). In rare autosomal recessive EB simplex associated with muscular dystrophy, mutations in the gene encoding plectin, a cytomatrix attachment protein, have been disclosed (25-27). In JEB, specific genetic lesions have been demonstrated in five different genes encoding hemidesmosome-anchoring filament complex proteins $(11,12)$. In the dystrophic forms of EB, over 100 distinct mutations in COL7A1, the gene encoding type VII collagen, have been disclosed (13).

Junctional EB (JEB) displays considerable phenotypic heterogeneity, and on the basis of clinical severity, the disease can be divided broadly into the classic, lethal (Herlitz) type and the nonlethal forms (23). Within the nonlethal forms, several subtypes have been delineated on the basis of the associated extracutaneous manifestations and the extent and severity of the blistering tendency. This clinical heterogeneity reflects the repertoire of underlying genetic lesions in several different candidate genes (15). The success in identifying these mutations has been based on technological advances that have allowed the development of efficient mutation detection strategies. One such technology, based on amplification of genomic DNA, followed by heteroduplex analysis and direct nucleotide sequencing, is designed to scan gene segments for sequence variations in a highly sensitive manner $(16,28)$. The efficiency of this strategy is shown by the fact that during the past 2 years, over 100 mutations in five different $\mathrm{BMZ}$ genes in different families with JEB have been disclosed; these include $B P A G 2, I T G B 4$, and the three laminin 5 genes, $L A M A 3, L A M B 3$, and $L A M C 2(12,15)$. However, most of the mutations characterized in the genes encoding the laminin 5 polypeptide chains in JEB are located in the $L A M B 3$ gene. This can be explained, at least in part, by the predominance of the R635X mutation (29), which accounts for about $40 \%$ of all laminin 5 mutations.

In this study, we report a strategy for evaluating $L A M C 2$ sequence variants in patients with JEB and illustrate the methodology by demonstrating previously undescribed mutations in $\mathrm{H}$ JEB patients as well as several novel polymorphisms in the $L A M C 2$ gene. One of the patients (Family 1) described above was shown to be a compound heterozygote for two mutations, both resulting in premature termination codons of translation in the $L A M C 2$ gene. The proband in another family (Family 3) was homozygous for a stop codon mutation, R95X. In the third family (Family 2), the proband had a paternal stop codon mutation, Q895X. In spite of extensive further analysis of $L A M C 2$, including direct sequencing of the entire coding region and flanking intronic sequences at least $20 \mathrm{bp}$ away from the intron-exon border, we failed to detect the maternal mutation in the proband of Family 2 . Similarly, in another previously described patient with nonlethal JEB, no evidence for the maternal mutation in $L A M C 2$ was found, while the paternal mutation was a mutation 2336del20 $\rightarrow$ G (ref. 21; no. 8 in Table 4). The inability to find the second mutation in these two patients could have several explanations. First, the mutation could be a regulatory one resulting in low or absent expression of the second allele, for example, due to a genetic lesion in the promoter region of the gene. Secondly, the undetected mutation could involve aberrant splicing due to a genetic lesion within an intron further 
TABLE 4. Pathogenetic mutations in the LAMC2 gene in patients with JEB

\begin{tabular}{|c|c|c|c|c|c|c|}
\hline $\begin{array}{l}\text { Patient } \\
\text { No. }\end{array}$ & Phenotype $^{a}$ & Genetic Status & Mutations & Verification & Consequence $^{b}$ & Reference \\
\hline 1 & H-JEB & $\begin{array}{l}\text { Compound } \\
\text { heterozygote }\end{array}$ & $\begin{array}{l}1154 \mathrm{delT} / \\
2986+1 \mathrm{G} \rightarrow \mathrm{A}\end{array}$ & MnlI/ASO & PTC/PTC & This study \\
\hline 2 & H-JEB & Homozygote & R95X & TaqI & PTC/PTC & This study \\
\hline 3 & H-JEB & $\begin{array}{l}\text { Compound } \\
\text { heterozygote }\end{array}$ & Q895X/? & ASO & $\mathrm{PTC} / ?$ & This study \\
\hline 4 & H-JEB & Homozygote & Y394X & ASO & PTC/PTC & 18 \\
\hline 5 & H-JEB & Homozygote & $1070 \mathrm{G} \rightarrow \mathrm{T}$ & ASO & $\mathrm{PTC/PTC}$ & 18 \\
\hline 6 & H-JEB & Homozygote & $\mathrm{R} 95 \mathrm{X}$ & $\operatorname{Taq} \mathrm{I}$ & $\mathrm{PTC} / \mathrm{PTC}$ & 20 \\
\hline 7 & NL-JEB & Homozygote & $1184-1 G \rightarrow A$ & ScaI & $\begin{array}{l}\text { In-frame exon } \\
\text { skip }\end{array}$ & 21 \\
\hline 8 & NL-JEB & $\begin{array}{l}\text { Compound } \\
\text { heterozygote }\end{array}$ & 2336del20 $\rightarrow$ G/? & Agarose gel & $\mathrm{PTC} / ?$ & 21 \\
\hline
\end{tabular}

${ }^{a}$ H-JEB, Herlitz type junctional EB; NL-JEB, nonlethal variant of junctional EB.

${ }^{b}$ PTC, premature termination codon for translation; the in-frame exon skip mutation was initially detected by RT-PCR.

away from the splice junction. This possibility is supported by a recent demonstration of a splicing error caused by 18 and $20 \mathrm{bp}$ deletions in the $P K D$ l gene within a 75 bp intron and resulting in polycystic kidney disease (30). Finally, there is the intriguing possibility that the second mutation in the patients resides in the gene for one of the other polypeptide subunits of laminin 5 . Theoretically, such complementary mutations could reduce the levels of normal laminin 5 trimeric molecules to $25 \%$ of the normal level and could conceivably result in a mild nonlethal phenotype. In addition to the patients described above, $L A M C 2$ mutations have previously been delineated in four other patients with JEB (Table 4). Three of these individuals were homozygous for premature termination codon mutations in $L A M C 2$ alleles and all had the lethal, Herlitz type of JEB (Patients 4-6 in Table 4) $(18,19,21)$. One of the patients (No. 7 in Table 4) was homozygous for an in-frame exon skip mutation resulting in a nonlethal variant of JEB (20). Collectively, the total number of allelic LAMC2 mutations in JEB disclosed thus far is 13, eight of them being distinct; the positions of these mutations within the $\gamma 2$ polypeptide are indicated in Fig. 4.

Examination of the database of laminin 5 mutations has allowed us to begin to formulate genotype-phenotype correlations in JEB. The molecular basis of H-JEB has been demonstrated to consist of premature termination codon mutations in both alleles of any of the three laminin 5 genes, $L A M A 3, L A M B 3$, or $L A M C 2$. Although these mutations predict the synthesis of a truncated, nonfunctional polypeptide, the major con-

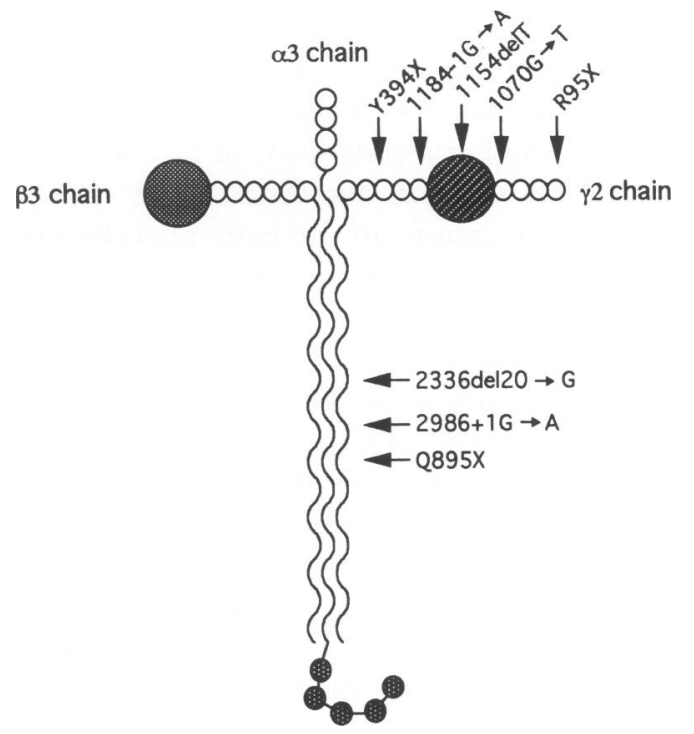

FIG. 4. Schematic representation of laminin 5 consisting of $\alpha 3, \beta 3$, and $\gamma 2$ chains

The diagram shows positions of mutations characterized thus far in the $L A M C 2$ gene in patients with junctional forms of epidermolysis bullosa. 
sequence of these mutations is most likely a markedly reduced level of the corresponding mRNA transcript resulting from the nonsensemediated mRNA decay (31). Since all three polypeptides are required for the assembly of trimeric laminin 5 molecules, no functional protein is formed as a result of these mutations. Consequently, staining with laminin 5 -specific antibodies, such as GB3 (22), is negative, and hemidesmosomes and anchoring filaments appear hypoplastic on electron microscopy, thus explaining the fragility of the skin at the level of the lamina lucida.

Within the nonlethal variants of JEB, laminin 5 gene mutations have also been disclosed, and in some cases the genetic lesion is a premature termination codon mutation in one of the alleles. However, in all cases of nonlethal JEB in which mutations in both alleles have been disclosed, the other mutation is a missense or an in-frame exon skipping mutation (see Table 4; refs. 12,20,32). These observations suggest that essentially full-length polypeptides with an intact carboxy-terminal end are able to incorporate into trimeric laminin 5 molecules and assemble into anchoring filaments, but the function of these filaments is compromised because of the presence of a second mutation. This interpretation is consistent with the observation that immunofluorescence with an anti-laminin 5 antibody is positive, although frequently attenuated, and the clinical severity is relatively mild in these nonlethal JEB patients (12).

In addition to pathogenetic mutations, neutral or silent polymorphisms have been demonstrated in the laminin 5 genes; those disclosed in the $L A M C 2$ gene thus far are listed in Table 3. Such polymorphisms, also delineated in the $L A M A 3$ and $L A M B 3$ genes $(28,33)$, can serve as informative markers in linkage studies to exclude laminin 5 genes as candidate genes in families with blistering skin diseases. This is especially useful, given the molecular heterogeneity of the junctional forms of EB.

Identification of mutations in the laminin 5 genes through technologies developed in this study for the $L A M C 2$ gene and as previously described for $L A M B 3$ (28) have profound implications for translational research in terms of prenatal testing in families at risk for recurrence of JEB. Specifically, mutation-based DNA testing can be performed from chorionic villus sampling during the first trimester of gestation, and scanning of laminin 5 genes by the technology developed in this study will significantly facilitate de- tection of the genetic lesions in patients with these devastating blistering diseases. DNA-based prenatal testing in JEB has already been reported for the $L A M A 3, L A M B 3$ and $L A M C 2$ genes (3436).

\section{ACKNOWLEDGMENTS}

We thank Yili $\mathrm{Xu}$, Lin Lin, Xin Zhang, and A. Spadafora for technical help. This study was supported by the U.S. Public Health Service, National Institutes of Health grant POI-AR38923, the Dermatology Foundation, INSERM-CNAMTS grant no. 4AIC24, Programme Hospitalier de Recherche Clinique, Ministere de l'Education Nationale (ACCSV), and the Dystrophic Epidermolysis Bullosa Research Associations of America and U.K.

\section{REFERENCES}

1. Burgeson RE, Chiquet N, Deutzmann R, et al. (1994) A new nomenclature for laminins. Matrix Biol. 14: 209-211.

2. Aumailley M, Krieg T. (1996) Laminins: A family of diverse multifunctional molecules of basement membranes. J. Invest. Dermatol. 106: 209-214.

3. Kallunki P, Sainio K, Eddy R, et al. (1992) A truncated laminin chain homologous to the B2 chain: structure, spatial expression and chromosomal assignment. J. Cell Biol. 119: 679-693.

4. Gerecke DR, Wagman DW, Champliaud MF, Burgeson RE. (1994) The complete primary structure for a novel laminin chain, the laminin Blk chain. J. Biol. Chem. 269: $11073-$ 11080.

5. Ryan MC, Tizard R, VanDevanter DR, Carter WG. (1994) Cloning of the LamA3 gene encoding the $\alpha 3$ chain of adhesive ligand epiligrin. Expression in wound repair. J. Biol. Chem. 269: 22779-22787.

6. Vailly J, Verrando P, Champliaud MF, et al. (1994) The 100-kDa chain of nicein/kalinin is a laminin B2 chain variant. Eur. J. Biochem. 219: 209-218.

7. Vidal F, Baudoin C, Miquel C, et al. (1995) Cloning of the laminin alpha 3 (LAMA3) and identification of a homozygous deletion in a patient with Herlitz junctional epidermolysis bullosa. Genomics 30: 273-280.

8. Pulkkinen L, Gerecke DR, Christiano AM, 
Wagman DW, Burgeson RE, Uitto J. (1995) Cloning of the $\beta 3$ chain gene (LAMB3) of human laminin 5 , a candidate gene in junctional epidermolysis bullosa. Genomics 25: 192-198.

9. Airenne T, Haakana H, Sainio K, et al. (1996) Structure of the human laminin $\gamma 2$ chain gene (LAMC2): alternative splicing with different tissue distribution of two transcripts. Genomics 32: 54-64.

10. Vailly J, Szepetowski P, Pedeutour F, et al. (1994) The genes for nicein/kalinin 125-kDa and $100-\mathrm{kDa}$ subunits, candidate for junctional epidermolysis bullosa, map to chromosome 1q32 and 1q25-31. Genomics 21: 286-288.

11. Uitto J, Pulkkinen L, Christiano AM. (1994) Molecular basis of the dystrophic and junctional forms of epidermolysis bullosa: Mutations in the type VII collagen and kalinin (laminin 5) genes. J. Invest. Dermatol. 103: 39S-46S.

12. Uitto J, McGrath JA, Pulkkinen L, Christiano AM. (1995) Molecular basis of the junctional forms of epidermolysis bullosa, a disorder of the cutaneous basement membrane zone. In: Proceedings of the 7th International Symposium on Basement Membranes. National Institutes of Health, Bethesda, MD, pp. 257-269.

13. Christiano AM, Uitto J. (1996) Molecular diagnosis of inherited skin diseases: The paradigm of dystrophic epidermolysis bullosa. Adv. Dermatol. 11: 199-213.

14. Christiano AM, Uitto J. (1996) Molecular complexity of the cutaneous basement membrane zone. Revelations from the paradigms of epidermolysis bullosa Exp. Dermatol. 5: $1-11$.

15. Uitto J, Pulkkinen L. (1996) Molecular complexity of the cutaneous basement membrane zone. Mol. Biol. Rep. 23: 35-46.

16. Ganguly A, Rock MJ, Prockop DJ. (1993). Conformation-sensitive gel electrophoresis for rapid detection of single-base differences in double-stranded PCR products and DNA fragments: Evidence for solvent-induced bends in DNA heteroduplexes. Proc. Natl. Acad. Sci. U.S.A. 90: 10325-10329.

17. Christiano AM, Anhalt G, Gibbons S, Bauer EA, Uitto J. (1994) Premature termination codons in the type VII collagen gene (COL7A1) underlie severe, mutilating recessive dystrophic epidermolysis bullosa. Genomics 21: 160-168.

18. Aberdam G, Galliano M-F, Vailly J, et al.
(1994) Herlitz's junctional epidermolysis bullosa is linked to mutations in the gene (LAMC2) for the $\gamma 2$ subunit of nicein/kalinin (laminin-5). Nature Genet. 6: 299-304.

19. Baudoin C, Miquel C, Gagnoux-Palacios L, et al. (1994) A novel homozygous nonsense mutation in the LAMC2 gene in patients with the Herlitz junctional epidermolysis bullosa. Hum. Mol. Genet. 3: 1909-1910.

20. Pulkkinen L, Christiano AM, Airenne T, Haakana H, Tryggvason K, Uitto J. (1994) Mutations in the $\gamma 2$ chain gene (LAMC2) of kalinin/laminin-5 in the junctional forms of epidermolysis bullosa. Nature Genet. 6: 293298.

21. Vailly J, Pulkkinen L, Christiano AM, et al. (1995) Identification of a homozygous exon skipping mutation in the LAMC2 gene in a patient with Herlitz's junctional epidermolysis bullosa. J. Invest. Dermatol. 104: 434437.

22. Verrando P, Blanchet-Bardon C, Pisani A, et al. (1991) Monoclonal antibody GB3 defines a widespread defect of several basement membranes and a keratinocyte dysfunction in patients with lethal junctional epidermolysis bullosa. Lab. Invest. 64: 85-92.

23. Fine J-D, Bauer EA, Briggaman RA, et al. (1991) Revised clinical and laboratory criteria for subtypes of epidermolysis bullosa. A consensus report by the subcommittee on diagnosis and classification of the national epidermolysis bullosa registry. J. Am. Acad. Dermatol. 24: 119-135.

24. McLean WHI, Leigh EB. (1995) Intermediate filaments in disease. Curr. Opin. Cell Biol. 7: 118-125.

25. McLean WHI, Pulkkinen L, Smith FJD, et al. (1996) Loss of plectin causes epidermolysis bullosa with muscular dysrophy: cDNA cloning and genomic organization. Genes Dev. 10: 1724-1735.

26. Smith FJD, Eady RAJ, Leigh IM, et al. (1996) Plectin deficiency results in muscular dystrophy with epidermolysis bullosa. Nature Genet. 13: 450-457.

27. Pulkkinen L, Smith FJD, Shimizu H, et al. (1996) Homozygous deletion mutations in the plectin gene (PLECl) in patients with epidermolysis bullosa simplex associated with late-onset muscular dystrophy. Hum. Mol. Genet. 5: 1539-1546.

28. Pulkkinen L, McGrath JA, Christiano AM, Uitto J. (1995) Detection of sequence variants in the gene encoding the $\beta 3$ chain of 
laminin 5 (LAMB3) by heteroduplex analysis of PCR amplified segments. Hum. Mutat. 6: 77-84.

29. Kivirikko S, McGrath JA, Pulkkinen L, Uitto J, Christiano AM. (1996) Mutational hotspots in the LAMB3 gene in the lethal (Herlitz) type of junctional epidermolysis bullosa. Hum. Mol. Genet. 5: 231-237.

30. Peral B, Gamble V, San Millan JL, et al. (1996) Splicing mutations of the polycystic kidney disease 1 (PKD1) gene induced by intronic deletion. Hum. Mol. Genet. 4: 569574.

31. Cooper DN. (1993) Human gene mutations affecting RNA processing and translation. Ann. Med. 85: 11-17.

32. McGrath JA, Pulkkinen L, Christiano AM, Leigh IM, Eady RAJ, Uitto J. (1995) Altered laminin 5 expression due to mutations in the gene encoding the $\beta 3$ chain (LAMB3) in generalized atrophic benign epidermolysis bullosa. J. Invest. Dermatol. 104: 467-474.

33. McGrath JA, Kivirikko S, Ciatti S, Moss C,
Christiano AM, Uitto J. (1996) A recurrent homozygous nonsense mutation within the LAMA3 gene as a cause of Herlitz junctional epidermolysis bullosa in patients of Pakistani ancestry: Evidence for a founder effect. J. Invest. Dermatol. 106: 781-784.

34. McGrath JA, Kivirikko S, Ciatti $S$, et al. (1995) A homozygous nonsense mutation in the $\alpha 3$ chain of laminin 5 (LAMA3) in Herlitz junctional epidermolysis bullosa: Prenatal exclusion in a fetus at risk. Genomics 29: 282-284.

35. Vailly J, Pulkkinen L, Miquel C, et al. (1995) Identification of a homozygous one basepair deletion in exon 14 of the LAMB3 gene in a patient with Herlitz junctional epidermolysis bullosa and prenatal diagnosis in a family at risk for recurrence. J. Invest. Dermatol. 104: 462-466.

36. Christiano AM, Pulkkinen L, McGrath JA, Uitto J. (1997) Mutation based prenatal diagnosis of Herlitz junctional epidermolysis bullosa. Prenatal Diag. (in press).

Communicated by D.J. Prockop. Accepted November 5, 1996. 